\title{
Prenatal diagnosis of Cantrell pentalogy in first trimester screening: case report and review of literature
}

\section{Birinci trimester anöploidi taramasında Cantrell pentalojisinin erken tanısı: olgu sunumu ve literatür taraması}

\author{
Mete Ahmet Ergenoğlu, A. Özgür Yeniel, Nuri Peker, Mert Kazandı, Fuat Akercan, Sermet Sağol \\ Department of Gynecology and Obstetrics, Faculty of Medicine, Ege University, Izmir, Turkey
}

\section{Abstract}

Pentalogy of Cantrell is a heterogeneous and rare thoraco-abdominal wall closure defect with the estimated prevalence of $1 / 65.000$ to $1 / 200.000$ births. Supraumbilical midline wall defect (generally omphalocele), deficiency of the anterior diaphragm and diaphragmatic peritoneum, defect of the lower sternum and several intracardiac defects are the components of Cantrell pentalogy. Etiology is unknown but a defect on the lateral mesoderm during the early stage of pregnancy is the most accepted hypothesis. Nowadays both 2- dimensional (2D) and 3-dimensional (3D) sonography are commonly used in diagnosis. In our case, a fetus with 11 weeks of gestation was reported as Cantrell pentalogy during first trimester screening. Additionally, unilateral limb defect and lumbar lordoscoliosis were detected through 3D sonography. Pregnancy was terminated according to parental desire. Karyotype was $46 \mathrm{XY}$. Early diagnosis is feasible in the first trimester if ectopia cordis and omphalocele exist. Additionally, development in ultrasound technology provides us with better visualization and early diagnosis. Prognosis seems to be poor in patients with complete Cantrell syndrome and patients with associated anomalies. Termination is the choice of treatment. Early diagnosis gives us a chance to reduce maternal morbidity and mortality related to termination.

(J Turkish-German Gynecol Assoc 2012; 13: 145-8)

Key words: Ectopia cordis, omphalocele, lower sternal defect, 3D sonography, Cantrell pentalogy

Received: 20 August, 2011

Accepted: 08 October, 2011
Özet

Cantrell Pentalojisi tahmini prevalansı 1/65.000 ile 1/200.000 doğumda bir izlenen heterojen ve nadir bir torako-abdominal duvara ait kapanma defektidir. Supraumblikal orta hat defekti (genellikle omfalosel), anterior diyafram ve diyafragmatik periton defekti, sternumun alt kısmına ait defektler ile kalbe ait anomaliler Cantrell Pentalojisini oluşturan bileşenlerdir. Etyolojisi bilinmemekle beraber erken gebelik haftalarında lateral mezoderme ait defektlerden kaynaklandığı hipotezi en geçerli olanıdır. Günümüzde tanıda hem iki hem de üç boyutlu sonografi kullanılmaktadır. Olgumuz birinci trimester taramasında Cantrell Pentalojisi tanısı alan 11. gebelik haftasındaki fetüs idi. Ek olarak tek taraflı alt ekstremite defekti ve lumbar lordoskolyoz üç boyutlu sonografide tespit edildi. Gebelik ailenin isteği üzerine termine edildi. Karyotip $46 \mathrm{XY}$ idi. Olgularda eğer ektopia kordis ve omfalosel mevcut ise birinci trimesterde erken tanısı mümkündür. Ek olarak ultrasonografi teknolojisindeki gelişmeler de bize daha iyi görüntüleme ve erken tanı imkanları sunmaktadır. Ek anomalilerin varlığında veya Cantrell Pentalojisinin tüm komponentlerini içeren olgularda prognoz kötüdür. Gebelik sonlandırması bu nedenle bir alternatif olarak göz önünde bulundurulmalıdır. Erken tanı bize gebelik sonlandırmasına ait mortalite ve morbiditenin azaltılması imkanı tanımaktadır.

(J Turkish-German Gynecol Assoc 2012; 13: 145-8)

Anahtar Kelimeler: Ektopia kordis, omfalosel, alt sternal defekt, 3 boyutlu sonografi, Cantrell pentaloji

Geliş Tarihi: 20 Ağustos 2011

Kabul Tarihi: 08 Ekim 2011

\section{Introduction}

Pentalogy of Cantrell is a heterogeneous and rare thoracoabdominal wall closure defect with the estimated prevalence of $1 / 65.000$ to $1 / 200.000$ births (1). Supraumbilical midline wall defect (generally omphalocele), defect of the anterior diaphragm and diaphragmatic peritoneum, defect of the lower sternum and several intracardiac defects are the components of Cantrell pentalogy (1,2). Primary anomalies are the ectopia cordis (EC) and omphalocele in this syndrome. Etiology is unknown but defect on the lateral mesoderm during the early stage of pregnancy is the most accepted hypothesis (3). Recently, both 2- dimensional (2D) and 3-dimensional (3D) sonography are commonly used in diagnosis. Differential diagnosis consists of isolated thoracic ectopia cordis, amniotic band syndrome, body stalk anomaly, Beckwidth-Wiedemann syndrome and physiologic midgut herniation $(2,3)$. Differential diagnosis is simple in physiologic midgut herniation related to the non-existent liver in the abdomen. Prognosis depends on the severity of lesions and associated anomalies. Therefore detailed anatomic assessment is essential for optimal prenatal counseling, pregnancy outcome and treatment policy (1-3). 


\section{Case report}

A 29-year-old pregnant woman gravida: 1 para: 0 was referred to the perinatalogy service for fetal posture anomaly at $11+0$ week of gestation. Ultrasonographic examination revealed ectopia cordis, herniated liver with large omphalocele including bowel loops, stomach and spleen (Figure 1). No cardiac anomaly was detected. The left unilateral femur was hypoplastic, tibia and fibula were absent, the left foot was directly connected to the left femur (Figure 2). Also, clubfoot deformity was detected on the left side. Thereafter, lumbar lordoscoliosis was identified (Figure 3). Umbilical cord appeared normal and there was no amniotic band. Pentalogy of Cantrell with limb defects was initially diagnosed. Genetic counseling was afforded and the parents opted for pregnancy termination. Single dose misoprostol was administered and 30 gr male fetus was aborted.

After abortion, macroscopic examination revealed the same findings as prenatal ultrasonography and also the lower limbs were adherent to each other (Figure 4a, b). Fetal karyotype was evaluated by dermal biopsy and detected $46 \mathrm{XY}$.

\section{Discussion}

Pentalogy of Cantrell is a very rare congenital anomaly with an estimated prevalence of $1 / 65.000$ to $1 / 200.000$ births (1). The etiology is unknown but defective formation, differentiation and migration of the lateral mesoderm at 14-18 days of embryonic life is the most accepted hypothesis (3). Most previous reported cases were sporadic but $\mathrm{X}$ chromosome gene mutation was involved in midline ventral disorders and in the literature, $\mathrm{X}$ linked inheritance has been suggested in some families (3).

Cantrell pentalogy may be present in different variations ranging from the protruding heart through the chest with omphalocele to anterior diaphragmatic hernia underdiagnosed until birth. In severe cases; the fetal heart protrudes through a wide sternal cleft but in mild forms, patients with small defects have partial anterior or transient or intermittent displacement of fetal heart. Abdominal wall defects present in many forms ranging from diastasis recti to large omphaloceles. A ' $\mathrm{V}$ ' shaped defect is observed in diaphragm herniation in Cantrell syndrome and a connection is present between peritoneal and pericardial cavity. Sternal defect should be partial or complete and may range from an absent xyphoid to various degrees of clefting $(4,5)$.

Cardiac anomalies such as ventricular septal defect, atrial septal defect, tetralogy of Fallot and ventricular diverticulum may accompany pentalogy of Cantrell. Ventricular septal defect (VSD) is the most commonly seen cardiac anomaly (6). Anencephaly, encephalocele, exencephaly hydrocephalus and craniorachischisis has been reported to be associated with Cantrell syndrome (6). Cleft lip and/or palate is the craniofacial anomaly accompanying Cantrell syndrome. Abdominal organ defects such as gallbladder agenesis and polysplenia may be the other attending anomalies. Vertebral anomalies such as dorsolumbar kyphoscoliosis and scoliosis are rare $(6,7)$. Clubfoot, absence of tibia or fibula or radius, hypodactily, ectrodactyly, phocomelia are associated limb defects and are reported only in a few papers in the literature (8). Pivnick et al. (9) reported an infant

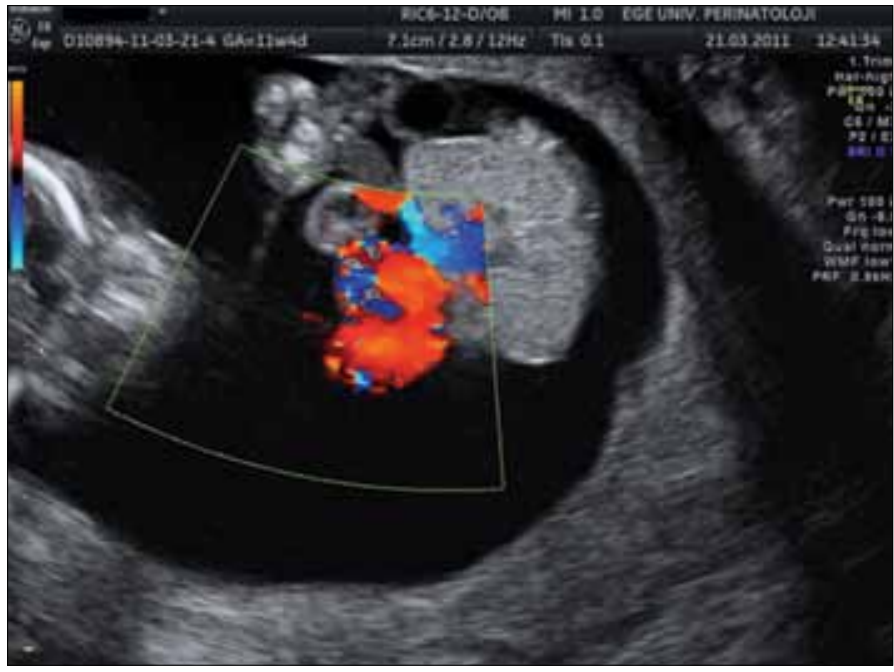

Figure 1. Large omphalocele and ectopia cordis are seen in color Doppler sonography

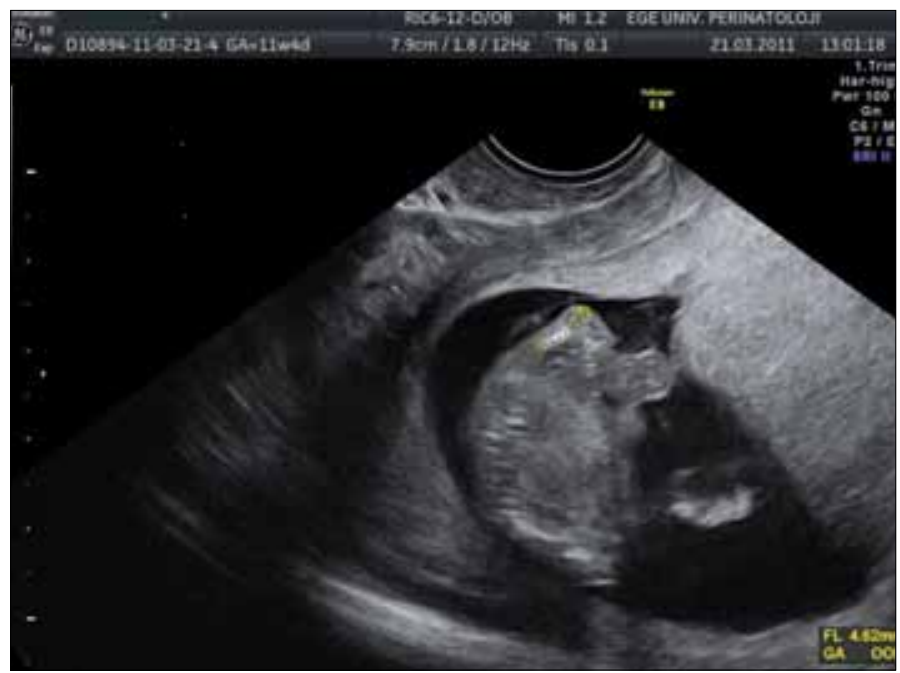

Figure 2. Left femur was hypoplastic, tibia and fibula were absent, left foot was directly connected to left femur

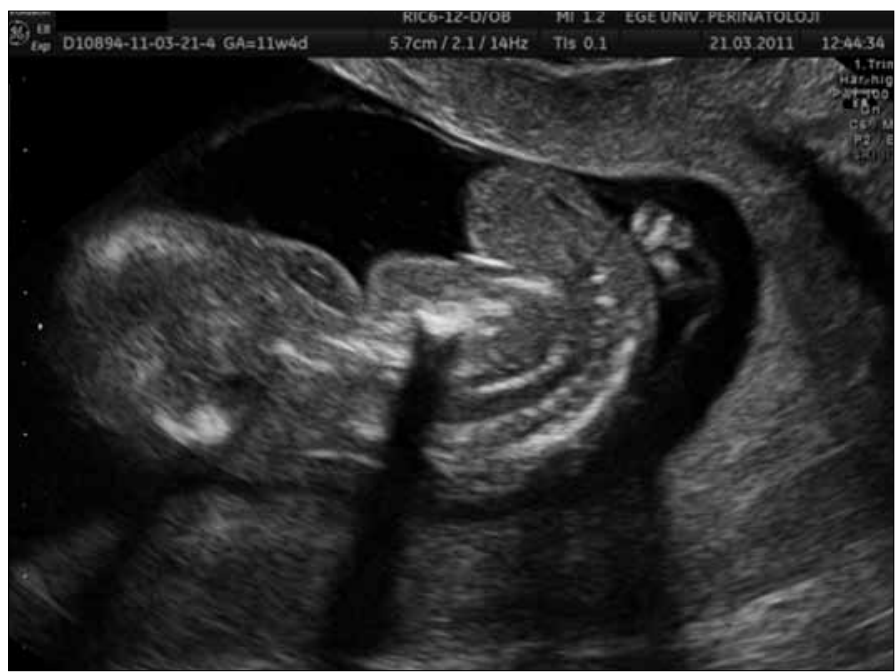

Figure 3. 2D sonographic appearance of lumbar lordoscoliosis 


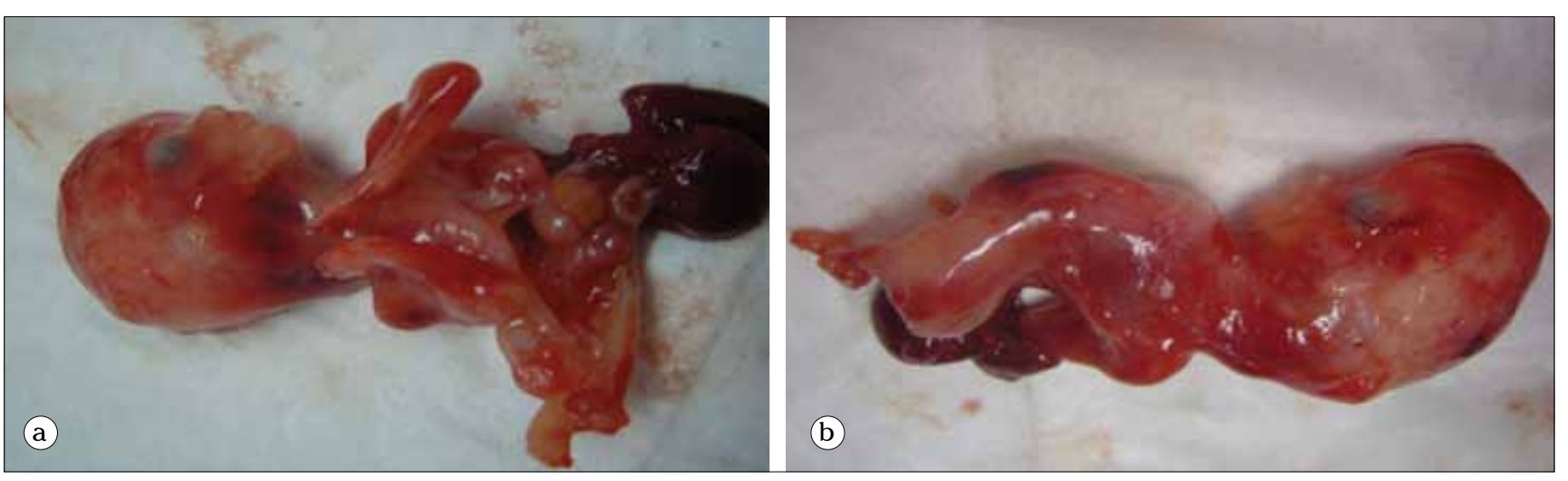

Figure 4. a) Defects which were diagnosed at the initial period were identical at pathologic examination, b) Prenatal sonographic examination of vertebral anatomy was consistent with pathologic examination

with midline thoracoabdominal syndrome with ectrodactyly and absence of right fibula and foot. Uygur et al. (10) reported an infant of Cantrell syndrome with limb defects. Chen et al. (11) reported a fetus with pentalogy of Cantrell and associated ectrodactyly and right upper limb hypoplasia. In our case report we observed a large omphalocele containing both bowels and liver. The heart protruded out and no cardiac anomaly was detected. In lower extremities left femur was hypoplasic, left tibia and fibula were absent and bilateral legs were adherent to each other (syrenomelia) which was reported rarely in literature. Also we identified lumbar lordoscoliosis by 3D scanning.

Prenatal diagnosis in the first trimester is simple if ectopia cordis and large omphalocele are detected with 2D ultrasonography. However, sometimes this may be difficult particularly in minor forms of ectopia cordis such as anterior, partial or transient displacement of the heart. Therefore transient pericardial effusion is an adjunct sonographic marker in diagnosis. 2D ultrasonography is commonly sufficient in diagnosis, but 3D scanning provides us with more detailed information about the fetal anatomy and malformations. The 3D mode is better in visualizing fetal bones because of greater contrast difference compared with adjacent organs. If pentalogy of Cantrell is suspected, detailed fetal anatomic assessment is necessary. In many cases a combination of 2D and 3D ultrasonography provide us with more details and sufficient images. MRI seems to be a complementary screening method for fetal anomalies. Fetal cardiac assessment should be done through fetal echocardiograpy. Chromosomal analysis is highly recommended due to the association with aneuploidy, particularly trisomy 18 . In our case, Cantrell syndrome was diagnosed at $11+0$ weeks of gestation with both 2D and 3D ultrasonography. In the differential diagnosis amniotic band syndrome must be kept in mind (12). Prognosis depends on the severity of cardiac lesions and associated anomalies. Treatment consists of corrective or palliative cardiovascular surgery, correction of diaphragmatic defects, ventral hernia and other associated anomalies. Success is related to the size of the omphalocele, ectopia cordis and associated heart anomalies $(13,14)$.

In such cases of fetal anomaly postmortem investigation must be performed. However, in our case the parents did not agree to an autopsy examination.
In conclusion, early diagnosis is feasible in the first trimester if ectopia cordis and omphalocele exist. Development in ultrasound technology provides us better visualization and early diagnosis. Prognosis seems to be poor in patients with complete Cantrell syndrome and patients with associated anomalies. Termination is the choice of treatment. Early diagnosis gives us a chance to reduce maternal morbidity and mortality related to termination.

\section{Conflict of interest}

No conflict of interest was declared by the authors.

\section{References}

1. Desselle C, Herve P, Toutain A, Lardy H, Sembely C, Perrotin F. Pentalogy of Cantrell: sonographic assessment. J Clin Ultrasound. 2007; 35: 216-20. [CrossRef]

2. Peixoto-Filho FM, do Cima LC, Nakamura-Pereira M. Prenatal diagnosis of Pentalogy of Cantrell in the first trimester: is 3-dimensional sonography needed? J Clin Ultrasound. 2009; 37: 112-4. [CrossRef]

3. Gün I, Kurdoğlu M, Müngen E, Muhcu M, Babacan A, Atay V. Prenatal diagnosis of vertebral deformities associated with pentalogy of Cantrell: the role of three-dimensional sonography? J Clin Ultrasound. 2010; 38: 446-9. [CrossRef]

4. Polat I, Gül A, Aslan H, Cebeci A, Ozseker B, Caglar B, et al. Prenatal diagnosis of pentalogy of Cantrell in three cases, two with craniorachischisis. J Clin Ultrasound. 2005; 33: 308-11. [CrossRef]

5. Murata S, Nakata M, Sumie M, Mastsuabra M, Sugino N. Prenatal diagnosis of pentalogy of Cantrell with craniorachischisis by threedimensional ultrasonography in the first trimester. Taiwan J Obstet Gynecol. 2009; 48: 317-8. [CrossRef]

6. van Hoorn $\mathrm{JH}$, Moonen RM, Huysentruyt $\mathrm{CJ}$, van Heurn LW, Offermans JP, Mulder AL. Pentalogy of Cantrell: two patients and a review to determine prognostic factors for optimal approach. Eur J Pediatr 2008; 167: 29-35. [CrossRef]

7. McMahon CJ, Taylor MD, Cassady CI, Olutoye OO, Bezold LI. Diagnosis of pentalogy of Cantrell in the fetus using magnetic resonance imaging and ultrasound Pediatr Cardiol 2007; 28: 172-5. [CrossRef]

8. Chen CP, Tzen CY, Chen CY, Tsai FJ, Wang W. Concomitant exencephaly and limb defects associated with pentalogy of Cantrell. Taiwan J Obstet Gynecol. 2008; 47: 476-7. [CrossRef]

9. Pivnick EK, Kaufman RA, Velagaleti GV, Gunther WM, Abramovici D. Infant with midline thoracoabdominal schisis and limb defects. Teratology 1998; 58: 205-8. [CrossRef] 
10. Uygur D, Kiş S, Sener E, Günçe S, Semerci N. An infant with pentalogy of Cantrell and limb defects diagnosed prenatally. Clin Dysmorphol 2004; 13: 57-8. [CrossRef]

11. Chen CP, Hsu CY, Tzen CY, Chern SR, Wang W. Prenatal diagnosis of pentalogy of Cantrell associated with hypoplasia of the right upper limb and ectrodactyly. Prenat Diagn 2007; 27: 86-7. [CrossRef]

12. Kutlu Dilek T, Yazıcı G, Gulhan S, Polat A, Dilek B, Dilek S. Amniotic Band Syndrome Associated With Cranial Defects and Ectopia
Cordis: A Report of Two Cases. J Turkish German Gynecol Assoc Vol 2005; 308-10.

13. Marino AL, Levy RJ, Berger JT, Donofrio MT. Pentalogy of Cantrell with a single-ventricle cardiac defect: collaborative management of a complex disease. Pediatr Cardiol 2011; 32: 498-502. [CrossRef]

14. O'Gorman CS, Tortoriello TA, McMahon CJ. Outcome of children with Pentalogy of Cantrell following cardiac surgery. Pediatr Cardiol. 2009; 30: 426-30. [CrossRef]

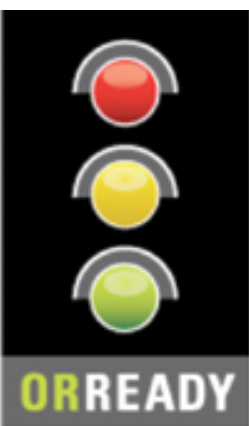

We are ORReady and support operating room safety to improve patient outcome.
ORReady is a worldwide, multi-Specialty initiative to encourage steps that are known to improve surgical outcomes and save lives.

If the suggested guidelines, which include Check Lists, Time Outs and Warm Ups are followed routinely, we estimate that Six Million patients around the world could have better outcomes.

Find out how your department and hospital can be ORReady and improve outcomes at http://www.sls.org/outcome 